\title{
MEASURING THE IMPACT OF INNER CITY MARKETS ON CBD RETAIL SALES
}

\author{
John B. Corgel \\ University of Florida \\ Truman A. Hartshorn \\ Georgia State University
}

\section{INTRODUCTION}

Observers of Central Business District (CBD) retailing performance have reported many adjustments in recent decades. Sales have steadily declined, relatively and absolutely, since World War II. The function and trade area of the CBD has changed, the clientele is different, and retail establishments have adopted new locational strategies. Contributing substantially to the changing character of CBDs has been the pervasive and continuing decentralization of the metropolitan population. Nearly two decades ago, Vance (1962) conceptualized the impact of this decentralization process as one of relegating the CBD to that of (1) a seller of mass appeal goods to an inner city market and (2) a seller of specialty goods to the metropolitan market. More recently, it appears that a scaling back has also occurred in the specialty goods area. Increasingly, specialty goods sales have been sustained by those who are downtown because of employment or business.

Empirical research in the past two decades has generally kept abreast of these changes, but has been almost entirely devoted to determining the importance of metropolitan-wide or city-wide market variables in explaining variation in aggregated CBD retail sales. ${ }^{i}$ The existence of a geographically segmented market for different types of CBD retail goods has never been directly tested for, or otherwise established, on statistical grounds. While prior aggregate specifications have fit the data well, a better understanding of the evolution and future direction of the CBD as a principal commercial center is needed. This understanding could be gained through further refinement of sales data and additional examination of the relationships contained therein.

The purpose of this paper is to provide a clearer perspective on the contemporary commercial function of metropolitan CBDs by determining how extensively the main components of $\mathrm{CBD}$ retail activity (convenience goods and shopping goods sales) are influenced by endemic market factors of the CBD's immediate trade area. Convenience goods, as defined by the U.S. Bureau of] the 
Census $(1965,1975)$, include items of mass appeal purchased in grocery stores, drug stores and the trade of eating and drinking establishments. Shopping goods include many specialty items and are defined by the U.S. Bureau of the Census $(1965,1975)$ as general merchandise, apparel and accessories, furniture and home furnishings. A final category, termed "other goods," includes items provided by building material suppliers, automotive dealers, gasoline service stations, and miscellaneous retail stores.

The CBD's immediate trade area, hereafter referred to as the inner city, includes a resident population living in close proximity to the commercial center and a population of captive customers located in the CBD for reasons of employment, business, conventions, or tourism. For purposes of this investigation, the contiguous census tracts lying within a 3-mile radius of the center of each CBD comprise the inner city. This definition approximates the primary trade area for CBD retail goods. ${ }^{\text {ii }}$

The next section of this paper contains a descriptive analysis of trends in CBD retail sales and inner city market changes during the past two decades. Aggregate and disaggregate sales relationships are presented in later sections. Cross-sectional data from 30 United States metropolitan areas for 1963 and 1972 are used in estimating parameters under the alternative assumptions of homoscedastic and heteroscedastic variances. The results of these analyses provide evidence that a segmented market exists for CBD retail trade. These results emphasize the importance of the inner city to $C B D$ retailing and affirm that the relationship between $\mathrm{CBD}$ employment and retail sales has remained strong. The policy analysis presented in the final section reflects these findings.

\section{CBD EMPLOYMENT AND RETAIL TRADE LEVELS}

The general relationship between CBD retail sales and employment is widely known, but specific quantitative assessments have rarely been pursued (Voorhees, Sharp, and Slegmaier, 1955; Ullman, French, and Meyers, 1967). The absence of comparative longitudinal CBD employment data is partially at fault. Planners in many cities can specifically pinpoint the levels of downtown employment for future periods (e.g., 1990 and 2000), but many do not have current figures. This dilemma posed problems in undertaking this research and played an important role in the selection process of the sample cities chosen for study. Table 1 shows the employment data obtained for 30 cities. These cities, over 250,000 in population, are located in all parts of the country and vary widely in size and function. 
TABLE 1.-CBD EMPLOYMENT LeVELS For StUdy Cities

\begin{tabular}{|c|c|c|}
\hline City & $1963^{a}$ & $1972^{\mathrm{a}}$ \\
\hline Atlanta & $85,806(1961)$ & $88,396(1971)$ \\
\hline Denver & 48,000 & 70,000 \\
\hline Wilmington & $20,352(1964)$ & $32,761(1971)$ \\
\hline Washington, D.C. & $231,000(1962)$ & $316,900(1973)$ \\
\hline Indianapolis & $85,027(1964)$ & $74,290(1973)$ \\
\hline Louisville & $38,257(1964)$ & $42,400(1975)$ \\
\hline Baltimore & $75,000(1964)$ & $83,400(1970)$ \\
\hline Buffalo & $50,000(1960)$ & $61,000(1970)$ \\
\hline Rochester & 29,190 & 41,580 (1973) \\
\hline Akron & 15,500 & 20,200 \\
\hline Columbus & $68,680(1964)$ & $82,723(1974)$ \\
\hline Dayton & $26,353(1965)$ & $29,668(1975)$ \\
\hline Pittsburgh & $119,025(1965)$ & $124,018(1975)$ \\
\hline Austin & 21,503 (1962) & $45,500(1970)$ \\
\hline Trenton & $21,152(1960)$ & $16,273(1970)$ \\
\hline Birmingham & $31,822(1965)$ & $49,456(1970)$ \\
\hline Providence & $39,872(1960)$ & 31,796 \\
\hline Richmond & $55,737(1964)$ & $58,216(1973)$ \\
\hline Salt Lake City & $32,399(1965)$ & 24,277 (1973) \\
\hline St. Louis & $140,255(1960)$ & $190,000(1970)$ \\
\hline Seattle & $101,468(1961)$ & $92,000(1973)$ \\
\hline Charlotte & $25,000(1960)$ & 40,000 \\
\hline San Jose & $21,003(1965)$ & $12,100(1970)$ \\
\hline EI Paso & $21,003(1965)$ & 15,779 (1975) \\
\hline Grand Rapids & $24,357(1965)$ & 19,895 \\
\hline Boston & 246,000 & 263,000 \\
\hline Nashville & 34,000 & $37,750(1970)$ \\
\hline Jacksonville & $17,080(1965)$ & 23,474 (1975) \\
\hline Cleveland & 117,000 & $125,000(1970)$ \\
\hline Milwaukee & 55,000 & $52,189(1970)$ \\
\hline
\end{tabular}

${ }^{\mathrm{a}}$ Years vary slightly from city to city, as indicated in parentheses. Source: Study questionnaire. 
Downtown employment averaged $17 \%$ of the SMSA work force in 1963 and $15 \%$ in 1972 for the cities under study. This relative employment decline, in terms of metropolitan-wide percentages, occurred even though most cities experienced total gains in absolute employment. CBD employment increases in these cities averaged $17 \%$ in the 1960 s, but figures for individual cities were quite variable. iii Whereas more than half of the cities registered greater than $10 \%$ increases in employment, nearly one-quarter experienced absolute employment decreases.

The average CBD retail sales level as a percentage of metropolitan sales in the 1960 s did not remain as strong as did employment. CBD sales for the entire sample dropped from an average level of 15\% of total SMSA sales in 1963 to $7 \%$ in 1972 after adjusting for inflationary changes (Table 2). Art average annual sales loss of $\$ 50$ million or more occurred in a typical city in 1972 compared with 1963. Very few cities had more than $10 \%$ of their sales in the CBD in 1972, and only two of the cities reported here, Salt Lake City and Birmingham, actually recorded real increases in sales during

TABLE 2.-CBD RETAIL SALES, 1963 AND 1972

\begin{tabular}{|c|c|c|c|}
\hline City & $\begin{array}{l}1963 \\
\text { CBD sales } \\
(\$ 1,000)\end{array}$ & $\begin{array}{l}1972 \\
\text { CBD sales } \\
(\$ 1,000)\end{array}$ & $\begin{array}{c}1972^{\mathrm{a}} \\
\text { Adjusted CBD sales } \\
(\$ 1,000)\end{array}$ \\
\hline $\begin{array}{l}\text { Atlanta } \\
\text { Denver } \\
\text { Wilmington } \\
\text { Washington, D.C. } \\
\text { Indianapolis }\end{array}$ & $\begin{array}{r}301,878 \\
168,130 \\
76,504 \\
406,930 \\
233,667\end{array}$ & $\begin{array}{r}320,382 \\
150,309 \\
61,108 \\
470,221 \\
178,875\end{array}$ & $\begin{array}{r}248,039 \\
116,369 \\
47,309 \\
364,045 \\
134,485\end{array}$ \\
\hline $\begin{array}{l}\text { Louisville } \\
\text { Baltimore } \\
\text { Buffalo } \\
\text { Rochester } \\
\text { Akron }\end{array}$ & $\begin{array}{r}209,857 \\
175,291 \\
150,559 \\
204,298 \\
98,066\end{array}$ & $\begin{array}{r}235,994 \\
208,135 \\
125,827 \\
208,038 \\
65,392\end{array}$ & $\begin{array}{r}182,706 \\
161,138 \\
97,415 \\
161,063 \\
50,626\end{array}$ \\
\hline $\begin{array}{l}\text { Columbus } \\
\text { Dayton } \\
\text { Pittsburgh } \\
\text { Austin } \\
\text { Trenton }\end{array}$ & $\begin{array}{r}225,382 \\
151,702 \\
299,449 \\
71,363 \\
72,356\end{array}$ & $\begin{array}{r}230,568 \\
134,481 \\
338,154 \\
83,586 \\
61,927\end{array}$ & $\begin{array}{r}178,505 \\
104,115 \\
261,798 \\
64,712 \\
47,943\end{array}$ \\
\hline $\begin{array}{l}\text { Birmingham } \\
\text { Providence } \\
\text { Richmond } \\
\text { Salt Lake City } \\
\text { St. Louis }\end{array}$ & $\begin{array}{l}150,005 \\
101,794 \\
123,906 \\
102,328 \\
193,331\end{array}$ & $\begin{array}{r}194,810 \\
82,363 \\
144,182 \\
143,766 \\
183,172\end{array}$ & $\begin{array}{r}150,821 \\
63,765 \\
111,625 \\
111,303 \\
141,811\end{array}$ \\
\hline $\begin{array}{l}\text { Seattle } \\
\text { Charlotte } \\
\text { San Jose } \\
\text { El Paso } \\
\text { Grand Rapids }\end{array}$ & $\begin{array}{r}225,332 \\
162,716 \\
113,057 \\
109,499 \\
85,395\end{array}$ & $\begin{array}{r}201,359 \\
153,044 \\
86,831 \\
114,990 \\
58,500\end{array}$ & $\begin{array}{r}155,892 \\
118,486 \\
67,224 \\
89,025 \\
45,290\end{array}$ \\
\hline $\begin{array}{l}\text { Boston } \\
\text { Nashville } \\
\text { Jacksonville } \\
\text { Cleveland } \\
\text { Milwaukee }\end{array}$ & $\begin{array}{r}406,826 \\
127,987 \\
94,833 \\
305,389 \\
148,374\end{array}$ & $\begin{array}{l}432,273 \\
138,978 \\
112,736 \\
277,917 \\
163,179\end{array}$ & $\begin{array}{r}334,665 \\
107,596 \\
87,280 \\
215,163 \\
126,333\end{array}$ \\
\hline
\end{tabular}

adjustment factor $=.7742$ based on Consumer Price Index. 1972.

Source: U.S. Bureau of the Census, Census of Business, 1963 and Census of Retall Trade, 
the period. In fact, an overall average decline of about 23\% occurred from 1963 to 1972 for CBD sales in this sample of cities.

\section{AGGREGATE CBD SALES}

A regression model of aggregate $C B D$ sales is presented in this section. The model is designed to represent the relationships between total CBD sales and measures of inner city market demand for retail goods. Discussion of the development and testing of the model is contained under the following subheadings: specification of the model, data and sampling procedures, method of estimation, and empirical results.

\section{Specification of the Model}

Demand for retail goods sold in the CBD is assumed to emanate from two distinct and differentiable inner city markets: (1) a resident population and (2) a population of captive customers previously defined. It is hypothesized that the relative importance of both markets has become more pronounced with the segmentation of the metropolitan retail market via the increasing dominance of outlying shopping centers.

The objective is to isolate the effects of inner city markets on CBD sales, ceteris paribus, but not to imply that the demand for CBD retail goods is entirely derived from the immediate trade area. Accordingly, CBD retail sales are assumed to be a function of CBD employment levels and CBD hotel rooms, as measures of captive market demand, and the population density, median family income, and racial composition of the inner city as measures of resident population demand.

The functional form of the aggregate model and the anticipated signs for the variables are as follows:

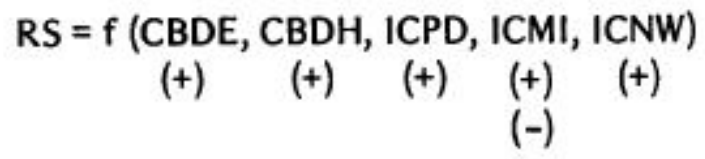

where, $\mathrm{RS}=$ dollar retail sales level in CBD

$\mathrm{CBDE}=$ Level of employment in CBD, by number of employees

$\mathrm{CBDH}=$ Number of hotel rooms in CBD

ICPD = Inner city population density

$\mathrm{ICMI}=$ Inner city median family income 
ICNW = Proportion of inner city resident nonwhite population.

The significance of CBD employment and hotel activity to CBD retail trade has received some prior consideration. In an early study, Vorhees et al. (1955) estimated that up to one-third of CBD sales is generated by CBD employment. Boyce and Clark (1963) reported a zero order correlation coefficient of .75 for the relationship between CBD sales and employment, while Friedman (1973) identified hotel rooms as being an important variable in CBD retail sales equations. A study of Washington, D.C. concluded that transient and office demand have been a source of stability for CBD retailing as a hedge against declines in residential demand (Ullman et al., 1967). The positive association between $\mathrm{CBD}$ employment and retailing was also substantiated in a recent descriptive analysis of major commercial districts conducted for HUD (International Downtown Executives Association and Real Estate Research Corporation, 1978). Concerns regarding the exodus of employment from CBDs, and the recent expansion of CBD hotel convention business, give these captive market factors added empirical relevance.

An inverse sign on the coefficient of the inner city variable may appear as a result of greater opportunities for shopping in commercial districts outside the inner city as household incomes rise. These opportunities follow from a higher incidence of multiple automobile ownership (McDonald, 1975). Finally, a positive association with sales is presupposed in the case of the nonwhite population variable because of a pronounced tendency toward greater nonwhite customer dependence on the CBD in recent decades (Cohen and Lewis, 1967).

The operational version of the model can be specified in the familiar linear form:

$$
\mathrm{RS}=b_{0}+b_{1} \mathrm{CDBE}+b_{2} \mathrm{CBDH}+b_{3} \mathrm{ICPD}+b_{4} \mathrm{ICMI}+b_{5} \mathrm{ICNW}+u
$$

where, $b_{i}(i=0,1 \ldots 5)$ are parameters and $u$ is a random error term.

\section{Data and Sampling Procedure}

As mentioned previously, the sampling of metropolitan areas for inclusion in the study was constrained by the availability of CBD employment data. In order to reach the sample size objective of 30 useable observations, CBD employment questionnaires were sent to a broad national audience of city and regional planning departments, downtown development organizations, and chambers of commerce in 62 metropolitan areas. ${ }^{\text {iv }}$ General eligibility was determined using the following 
criteria:

1. The study was limited to metropolitan areas with 1970 urbanized area populations of at least 250,000 persons.

2. Retail sales data must have been available from Bureau of the Census publications in both 1963 and 1972. Further, areas, such as Houston, were excluded because of changes made in the boundary of the CBD during the period.

3. Metropolitan areas having two or more CBDs with sufficiently large sales volumes were excluded from consideration. Specifically, if $25 \%$ or more of the combined sales of two competing CBDs in the same metropolitan area could be attributed to the smaller CBD, then the area was excluded. An example is the DallasFort Worth metropolitan area.

In addition, the three largest metropolitan areas in the U.S., New York, Los Angeles, and Chicago, were not considered in selecting the sample because of their relative size. The final sample resulted in a fairly even distribution among the 30 metropolitan areas by

Population-Over 2 million, 6; between 1 and 2 million, 8; between 500,000 and 1 million, 10; between 500,000 and 250,000, 6; and

Geographic Regions - Northeast, 7; North Central, 8; South, 11; and West, 4.

The questionnaire requested information on how CBDs have been defined; it asked for CBD employment data in 1963 and 1972, and provided space for the respondent to offer additional information, including alternative data sources. The data were checked against estimates published in area transportation studies and compared with decennial census figures. In about $40 \%$ of the cases, the data received did not correspond exactly with annual period estimates that were requested. For 1963 figures, if data were not provided within the interval 1960 to 1964 , the sample city was no longer considered for inclusion in the study. Similarly, the city was rejected if data for the 1970 to 1974 period were not available to correspond with the 1972 target date.

With the exception of figures for CBD hotel rooms, the balance of the data were obtained from census publications. ${ }^{\vee}$ The number of hotel rooms in each CBD was calculated from hotel directories published annually by the American Hotel Association Directory Company $(1963,1972)$. The location of a particular hotel, i.e., downtown or suburban, was provided in the 1972 edition of the directory, but not in 1963. Locational determinations for 1963 were accomplished with the aid of city maps. 


\section{Method of Estimation}

Parameters in equation (2) are estimated using ordinary least squares (OLS), i.e., a standard multiple regression analysis. While the variables were observed at slightly different points in time, the measurement error is not considered severe enough to warrant data correction procedures, since the variables measured for the empirical analysis are not subject to large variations from year to year.

Rudimentary tests conducted on the data did affirm the likelihood of heteroscedastic variances. ${ }^{\mathrm{vi}}$ This suggests that the error term, $u$, may not have a common variance across observation units. Since metropolitan areas with over 2 million and less than 500,000 persons are included in the sample, the possibility that the common variance assumption might be violated is not altogether surprising. An appropriate technique for dealing with this type of problem is weighted least squares (WLS). With the WLS specification, each observation is divided, or weighted, by the inverse of the standard deviation from its corresponding error term obtained previously from an OLS estimation (see Theil, 1971, pp. 245-246). Thus, WLS estimates of the parameters are reported along with OLS estimates for the aggregate model.

\section{Empirical Results}

Results from the OLS and WLS estimation of the coefficient vector are provided in Table 3. The WLS estimates are only slightly better for both the 1963 and 1972 coefficients. The percent of variation in retail sales explained by the inner city variable $\left(R^{2}\right)$ is lower using WLS in 1963 and about the same as in the OLS equations for 1972 . The variables in the model performed much as anticipated, with the exception of CBD hotel rooms in the 1963 analysis. ${ }^{\text {vii }}$ Whereas the coefficient on hotel rooms is negative in the 1963 equation, it is quite small and not significantly different from zero. Most importantly, CBD employment is the dominant independent variable for both periods. In each instance, $\mathrm{CBD}$ employment explains about $70 \%$ of the variation in $\mathrm{CBD}$ retail sales.

The results of the aggregate analysis are surprisingly good when considering that the model does not attempt to represent influences from the remaining central city and suburban resident markets. One is tempted to associate these outside influences with the estimated intercept of the model. It is true that $b_{0}$ in equation (2) can be regarded as the estimate of the dependent variable when all the independent variables are equal to zero, i.e., the mean amount of CBD sales not related to the 
TABLE 3.-THE ESTIMATED EFFECTS OF INNER CITY MARKET VARIABLES ON AGGREGATE CBD RETAIL SALES

\begin{tabular}{|c|c|c|c|c|c|c|c|c|c|}
\hline $\begin{array}{l}\text { Dependent } \\
\text { variable }\end{array}$ & Intercept & CBDE & $\mathrm{CBDH}$ & ICPD & ICMI & ICNW & $R^{2}$ & $\mathbf{N}$ & $\mu$ \\
\hline \multicolumn{10}{|l|}{ RS63 } \\
\hline A. OLS & 124.198 & $\begin{array}{l}.0014^{*} \\
(5.22)\end{array}$ & $\begin{array}{l}-.0023 \\
(.35)\end{array}$ & $\begin{array}{l}.0017 \\
(.44)\end{array}$ & $\begin{array}{r}-.0105 \\
(1.19)\end{array}$ & $\begin{array}{l}.2598 \\
(.50)\end{array}$ & .82 & 30 & 176.54 \\
\hline \multirow{2}{*}{$\begin{array}{l}\text { B. WLS } \\
\text { RS72 }\end{array}$} & 111.258 & $\begin{array}{l}.0014^{*} \\
(5.25)\end{array}$ & $\begin{array}{c}-.0015 \\
(.83)\end{array}$ & $\begin{array}{l}.0009 \\
(1.14)\end{array}$ & $\begin{array}{c}-.0077^{*} \\
(3.69)\end{array}$ & $\begin{array}{l}.3277 \\
(.84)\end{array}$ & .74 & & \\
\hline & & & & & & & & & \\
\hline A. OLS & 116.853 & $\begin{array}{l}.0008 * \\
(2.88)\end{array}$ & $\begin{array}{l}.0100 \\
(1.06)\end{array}$ & $\begin{array}{l}.0038 \\
(.49)\end{array}$ & $\begin{array}{c}-.0077 \\
(.70)\end{array}$ & $\begin{array}{l}.3656 \\
(.58)\end{array}$ & .77 & 30 & 178.70 \\
\hline 8. बक्ष & 105.964 & $\begin{array}{l}.0010^{*} \\
(2.98)\end{array}$ & $\begin{array}{l}.0075^{*} \\
(1.83)\end{array}$ & $\begin{array}{l}.0043 \\
(.77)\end{array}$ & $\begin{array}{r}-.0072 \\
(1.23)\end{array}$ & $\begin{array}{r}.4613 \\
(.54)\end{array}$ & .79 & & \\
\hline
\end{tabular}

Nc:ig: rosutis.. is shown in parentheses. "significant at the .05 level.

inner city variables. Such interpretations are suspect, however, when sample values lie some distance from the origin as in this case.

\section{DISAGGREGATE SALES EVALUATION}

The model using total CBD sales as a dependent variable merely provides the basis for an indirect test of the assertion that the principal retail function of CBDs has evolved into one of supplying goods to the inner city. A disaggregate analysis of CBD sales offers a more direct test. In this section, the model presented in equation (2) is reformulated with CBD shopping goods and CBD convenience goods sales taken separately as the dependent variables. $A$ presentation of results from these analyses follows a discussion of the disaggregate sales data.

\section{Disaggregate Sates Data}

Shopping goods have remained the dominant component of CBD sales, although convenience goods and other goods also make sizable contributions. An advantage of disaggregating CBD sales for analysis purposes beyond those stated above is that other goods sales can be effectively excluded. Because census tracts are utilized in defining the CBD by the Census Bureau, retail trade from traditionally non-CBD business establishments, such as automotive dealerships and building material suppliers, is included as part of total CBD trade. These sales can be easily removed since they are reported as other goods sales. Other $\mathrm{CBD}$ researchers have treated this problem by employing alternative techniques of delimiting the CBD. viii

A breakdown of aggregate CBD sales among the convenience and shopping 
goods categories for the sample metropolitan CBDs is shown in Table 4. Of total CBD sales in 1963,14\% were recorded in the convenience group while $64 \%$ were registered in the shopping group. Both had greater shares in 1972, rising to approximately $16 \%$ and $67 \%$, respectively. When shopping goods and convenience goods are combined, they accounted for $78 \%$ of total CBD sales in 1963 and $83 \%$ in 1972 . The remaining sales are attributable to the other goods category.

\section{Findings}

Separate OLS runs were made for shopping goods and convenience goods sales in an effort to determine the underlying relationships between inner city market variables and CBD sales. The a priori relationships specified in the functional form of the aggregate model are also appropriate for this part of the analysis. Since the net effect of applying the WLS procedure in the aggregate analysis is unclear, the approach was not implemented as part of the disaggregate analysis. The OLS results are provided in Table $5 .{ }^{\text {ix }}$

The dominant influence that CBD employment exerts over total CBD sales was repeated in the shopping goods model for both the 1963 and 1972 periods. This result is not surprising, since shopping goods expenditures constitute such a large share of total retail expenditures in the CBD. But it does strongly emphasize that the retailing needs of those employed downtown must be met by CBD merchants. All other variables in the shopping goods model were not significantly different from zero, but, again, CBD hotel rooms had an unexpected negative sign. While strong statement about shopping goods sales and hotel activity are impossible due to their lack of statistical significance, the importance of hotel rooms to the convenience goods sales model does provide support for the development of an additional hypothesis.

One might conjecture that shopping goods retailing and hotel activity are not complementary CBD functions. Thus, an increase in hotel activity would be accompanied by the substitution of convenience goods establishments for those providing shopping goods. CBD transients apparently 
TABLE 4.-CBD CONVENIENCE AND SHOPPING GOOdS SALES, 1963 AND 1972

$(\$ 1,000)$

\begin{tabular}{|c|c|c|c|c|}
\hline \multirow[b]{2}{*}{ City } & \multicolumn{2}{|c|}{1963} & \multicolumn{2}{|c|}{$1972^{\mathrm{a}}$} \\
\hline & $\begin{array}{l}\text { Convenience } \\
\text { goods }\end{array}$ & $\begin{array}{l}\text { Shopping } \\
\text { goods }\end{array}$ & $\begin{array}{l}\text { Convenience } \\
\text { goods }\end{array}$ & $\begin{array}{l}\text { Shopping } \\
\text { goods }\end{array}$ \\
\hline Atlanta & 33.3 & 152.6 & 34.7 & 141.5 \\
\hline Denver & 28.0 & 94.3 & 24.3 & 68.4 \\
\hline Wilmington & 15.2 & 42.2 & 12.2 & D \\
\hline Washington, D.C. & 91.7 & 240.9 & 94.2 & 233.0 \\
\hline Indianapolis & 29.8 & 137.9 & 19.4 & 98.3 \\
\hline Louisville & 28.4 & 89.3 & 25.2 & 67.7 \\
\hline Baltimore & 27.9 & 123.6 & 27.2 & 125.3 \\
\hline Buffalo & 36.5 & 91.1 & 18.3 & 73.8 \\
\hline Rochester & 22.3 & 120.3 & 17.5 & 92.4 \\
\hline Akron & 11.0 & 73.2 & D & D \\
\hline Columbus & 47.4 & 203.9 & D & D \\
\hline Dayton & 15.7 & 114.6 & 11.6 & D \\
\hline Pittsburgh & 41.8 & 227.9 & 39.9 & 175.4 \\
\hline Austin & 7.1 & 28.1 & 7.2 & D \\
\hline Trenton & 8.5 & 53.4 & 6.2 & 36.4 \\
\hline Birmingham & 23.5 & 97.1 & D & 102.8 \\
\hline Providence & 11.6 & 79.9 & 9.5 & D \\
\hline Richmond & 19.9 & D & 16.1 & 82.3 \\
\hline Salt Lake City & 15.2 & 63.0 & D & 70.7 \\
\hline St. Louis & 20.5 & 154.2 & D & D \\
\hline Seattle & 34.6 & 153.2 & 27.2 & 114.8 \\
\hline Charlotte & 7.9 & 68.2 & 6.9 & 59.7 \\
\hline San Jose & 20.8 & 47.2 & 16.9 & 27.6 \\
\hline EI Paso & 10.0 & 66.2 & 9.2 & 72.5 \\
\hline Grand Rapids & 7.8 & 60.1 & D & 32.1 \\
\hline Boston & 74.1 & 278.5 & 63.5 & 243.6 \\
\hline Nashville & 12.4 & 689.1 & 9.6 & 84.8 \\
\hline Jacksonville & 12.6 & 69.3 & 7.8 & 74.3 \\
\hline Cleveland & 47.4 & 203.9 & D & 141.6 \\
\hline Milwaukee & 22.1 & 103.9 & 25.4 & 92.6 \\
\hline
\end{tabular}

${ }^{\text {a }}$ Figures adjusted for inflation. D-Information withheld due to disclosure rule.

Source: See Table 2.

do not support the shopping goods market as exclusively as some observers and developers might anticipate. Moreover, eating and drinking sales are reported as convenience goods by the census. Although the substitution hypothesis is not tested in this study, observation of retailing adjustments occurring in major convention cities in the 1970 s (e.g., Atlanta, Washington, D.C., Dallas) lends indirect support to its validity.

Inner city resident market variables have a greater impact in the convenience goods models, but were less important than captive market variables in 1972 than in 1963. Only the CBD hotel rooms variable is significant at the $5 \%$ level in both the 1963 and 1972 convenience goods equations. Moreover, the 
improvement in $R^{2}$ from 1963 to 1972 results from the emergence of employment as an important variable to convenience goods sales. The convenience goods equation works very well in 1972 as a result of the combined influence of inner city captive and resident market factors. The

TABLE 5.-THE ESTIMATEd EFFECTS OF INNER CITY MARKET VARIABLES ON CBD SHOPPING AND CONVENIENCE GOODS SALES

\begin{tabular}{|c|c|c|c|c|c|c|c|c|c|}
\hline $\begin{array}{l}\text { Dependent } \\
\text { variable }\end{array}$ & Intercept & CBDE & $\mathrm{CBDH}$ & ICPD & ICMI & ICNW & $\mathrm{R}^{2}$ & $\mathrm{~N}$ & $\mu$ \\
\hline SHOP 63 & 66.680 & $\begin{array}{l}.0011^{* *} \\
(5.94)\end{array}$ & $\begin{array}{r}-.0059 \\
(1.27)\end{array}$ & $\begin{array}{l}.0034 \\
(1.28)\end{array}$ & $\begin{array}{r}-.0073 \\
(1.22)\end{array}$ & $\begin{array}{l}.2067 \\
(.55)\end{array}$ & .84 & 29 & 114.72 \\
\hline CONV 63 & 14.154 & $\begin{array}{l}.00002 \\
(.28)\end{array}$ & $\begin{array}{l}.0034 * * \\
(1.79)\end{array}$ & $\begin{array}{l}.0022 * \\
(2.05)\end{array}$ & $\begin{array}{c}-.0041^{*} \\
(1.64)\end{array}$ & $\begin{array}{l}.0963 \\
(.66)\end{array}$ & .58 & 30 & 24.16 \\
\hline SHOP 72 & 104.897 & $\begin{array}{l}.0010^{* *} \\
(5.56)\end{array}$ & $\begin{array}{r}-.0057 \\
(1.08)\end{array}$ & $\begin{array}{l}.0022 \\
(.49)\end{array}$ & $\begin{array}{r}-.0078 \\
(1.07)\end{array}$ & $\begin{array}{l}.0820 \\
(.23)\end{array}$ & .87 & 23 & 129.92 \\
\hline CONV 72 & 7.068 & $\begin{array}{l}.0022 * * \\
(5.20)\end{array}$ & $\begin{array}{l}.0024^{*} \\
(1.74)\end{array}$ & $\begin{array}{l}.0013^{*} \\
(1.31)\end{array}$ & $\begin{array}{c}-.0011 \\
(.64)\end{array}$ & $\begin{array}{c}-.027 \\
(.33)\end{array}$ & .95 & 23 & 29.79 \\
\hline
\end{tabular}

Note: $t$-statistic in parentheses; *significant at the .05 level; **significant at the .10 level.

shopping goods equations, like the aggregate sales equations, work because of the strong influence of CBD employment. These findings indicate that the inner city captive market is not as crucial to the strength of shopping goods sales as it is to convenience goods items. The overall lower per capita buying power of this market in comparison to the captive employment market is no doubt a major contributing factor to the contrasting support base for the convenience and shopping goods market.

\section{POLICY IMPLICATIONS AND CONCLUSIONS}

Downtown business organizations have generally been slow to adjust to their current market, which is considerably different from a decade or more ago. Sales will continue to fall until entrepreneurs have fully adjusted to their market. Some entrepreneurs operate at a fantasy level in believing they can lure the middle class downtown to shop, whereas others feel that the emerging hotel convention market is their target. Cities that have opted to build downtown pedestrian malls or enclosed shopping centers have similarly not found them automatic panaceas for retailing (Cunningham, 1978).

The results of this study bring to bear the reality facing downtown entrepreneurs, i.e., they must cater to the inner city residential market and to the captive transient employee market in the area. In some older, high density cities where there may be a greater abundance of close-in middle and high income groups, a broader spectrum of merchandise can be offered. In the majority of cities, however, this segment of the market is absent. Those working downtown want moderately priced mass appeal shopping goods and 
convenience items, not elite specialty goods. Families with low to moderate income who live within a few miles of downtown also need moderately priced mass appeal goods.

Most CBDs have too few outlets that offer mass appeal merchandise in the moderate price range. Instead, many retailers have opted for boutiques, highbrow apparel outlets, import shops, and other specialty stores directed at the transient and worker market. Some new downtown outlets are located in megastructures in an overdesigned environment selling exclusive overpriced merchandise. In short, such retailers have overbuilt and overshot their market. Entrepreneurs rationalize this behavior as an attempt to bring in the middleclass, fashion-conscious shopper. This strategy is generally not successful. Exceptions mainly occur in downtowns that are already strong in retailing, such as in Salt Lake City.

Downtowns also have other problems, not the least of which is their poor internal spatial structure with respect to retailing. After decades of retrenchment, retailing outlet closures, selective urban renewal, and the appearance of newer office and hotel developments, the downtown retail scene is rarely a compact, functional entity. More typically, it is dispersed and fragmented spatially with several competing nodes that do not provide the critical mass for success (Dent, 1978). Finally, downtown retailing may not fare well with higher cost energy in the future. Shopping trips are already predominantly to suburban outlets which are closer to their target markets than the CBD. Downtown retail sales will stabilize only when CBD outlets have fully adjusted to their roles as the mass appeal goods seller to those working downtown and/or living nearby.

\section{LITERATURE CITED}

American Hotel Association Directory Company, 1963,1972, Hotel and Motel Red Book. New York.

Boyce, Ronald R. and Clark, William A. V., 1963, Selected spatial variables and central business district retail sales. Papers and Proceedings, Regional Science Association, Vol. 11,167-193.

Briggs, Ronald, 1974, A model to relate the size of the central business district to the population of a city. Geographical Analysis, Vol. 6,165-179.

Casparis, John, 1967, Metropolitan retail structure and its relations to 
population. Land Economics, Vol. 43, 212-218.

Cohen, Saul B. and Lewis, George, 1967, Form and function in the geography of retailing. Economic Geography, Vol. 42,1-42.

Cunningham, Michael C., 1978, Can downtown be reinvented? Ekistics, Vol. 256,159-164.

Dent, Borden D., 1978, The challenge to downtown shopping. Atlanta Economic Review, Vol. 28, 29-33.

Friedman, Judith J., 1973, Variations in the level of central business district retail activity among large U.S. cities, 1954 and 1967. Land Economics, Vol. 49, 326335.

Goldfield, Stephen M., and Quandt, Richard E., 1965, Some tests of homoscedasticity. Journal of American Statistical Association, Vol. 60,539-547.

International Downtown Executives Association and Real Estate Research Corporation, 191\%, Analysis of Major Commercial Districts. Executive Summary. Washington, D.C.; Prepared for the Department of Housing and Urban Development.

Kottis, George C. and Kottis, Athenia, 1972, A statistical exploration of some factors responsible for decline of the central business district. Land Economics, Vol. 48,169-173.

McDonald, John F., 1975, Some causes of the decline of central business district retail sales in Detroit. Urban Studies, Vol. 12, 229-233.

Murphy, Raymond E., 1972, The Central Business District. Chicago: Aldine Atherton.

Russwurm, Lome H., 1964, The central business district retail sales mix, 19481958. Annals of the Association of American Geographers, Vol. 54, 524-536.

Taeuber, Alma F., 1964, Population redistribution and retail changes in the central business district. In E. W. Burgess and D. J. Bogue, editors, Contributions to Urban Sociology. Chicago: University of Chicago Press, 164-178.

Theil, Henri, 1971, Principles of Econometrics. Santa Barbara: John Wiley \& Sons.

Ullman, Edward L., French, V. O., and Meyers, C. S., 1967, Trends in CBD and SMSA sales, 1948-1963. Washington, D.C.: Center for Metropolitan Studies.

U.S. Bureau of the Census, 1962, U.S. Census of Population and Housing: 1960 Census Tracts. Washington, D.C.: GPO.

U.S. Bureau of the Census, 1965, Census of Business, 1963. Retail Trade: Major Retail Centers. Washington, D.C.: GPO. 
U.S. Bureau of the Census, 1972, U.S. Census of Population and Housing: 1970 Census Tracts. Washington, D.C.: GPO.

U.S. Bureau of the Census, 1975, Census of Retail Trade, 1972. Retail Trade: Major Retail Centers. Washington, D.C.: GPO.

Vance, James E., Jr., 1962, Emerging patterns of commercial structure in American cities, Proceedings of the i.G.U. Symposium in Urban Geography, Lund, 1960. Lund: C.W.K. Gleerup Publishers, 485-515.

Voorhees, Alan M., Sharp, G. B., and Slegmaier, J. T., 1955, Shopping Habits and

Travel Patterns. Special Report, 11B, Washington, D.C.: Highway Research Board.

\section{Notes}

i See Taeuber (1964); Casparis (1967); Kottis and Kottis (1972); Boyce and Clark (1963); Friedman (1973); Briggs (1974); and McDonald (1975).

ii This method of delimiting inner city boundaries was selected because of an absence of a more appropriate definition, in no instance did the approach lead to the inclusion of nonhomogeneous census tracts.

iii The standard deviation of the change in employment, 1963 to 1972, for the 30 cities was about $31 \%$.

iv All data for the study were collected during the first six months of 1976.

$\checkmark$ Retail sales data were obtained directly from U.S. Bureau of the Census (1965 and 1975). Inner city population density, median income, and percent nonwhite population data were calculated from U.S. Bureau of the Census (1962 and 1972).

vi The problem arises from wide variations in population size within the sample of metropolitan areas. See Goldfield and Quandt (1965) for a discussion of homoscedasticity tests.

vii As previously suggested, the negative sign on the coefficient of the income variable stems from increased automobile ownership as incomes rise, and therefore greater opportunity to shop in outlying centers. This result is not altogether surprising given the work of McDonald (1975).

viii See Murphy (1972), Boyce and Clark (1963), and Russwurm (1964).

ix The number of observations for the disaggregate analysis varies because of U.S. Bureau of the Census disclosure rules. Briefly, if there are few reporting establishments in a 
commercial center for a single type of good, then the totals are not published in order to maintain establishment anonymity. 